\title{
AXIN1 Expression and Localization in Meningiomas and Association to Changes of APC and E-cadherin
}

\author{
NIVES PEĆINA-ŠLAUS ${ }^{1,2}$, ANJA KAFKA $^{1,2}$, TOMISLAV VLADUŠIĆ ${ }^{3}$, \\ HRVOJE IVAN PEĆINA ${ }^{4}$ and RENO HRAŠĆAN ${ }^{3}$ \\ ${ }^{1}$ Laboratory of Neurooncology, Croatian Institute for Brain Research, \\ School of Medicine University of Zagreb, Zagreb, Croatia; \\ ${ }^{2}$ Department of Biology, School of Medicine, University of Zagreb, Zagreb, Croatia; \\ ${ }^{3}$ Department of Biochemical Engineering, Faculty of Food Technology and Biotechnology, \\ University of Zagreb, Zagreb, Croatia; \\ ${ }^{4}$ Department of Radiology, Hospital Center "Sisters of Mercy", Zagreb, Croatia
}

\begin{abstract}
Background/Aim. Tumor suppressor gene AXIN1 is an inhibitor of Wnt signaling pathway. It down-regulates the pathway's main signaling effector molecule, betacatenin, in an AXIN-based destruction complex. In the present study we investigated the involvement of AXIN1 in intracranial meningioma. Materials and Methods: Loss of heterozygosity and microsatellite instability analyses were performed. The consequences of genetic changes on protein expression levels were studied in the same patients by immunohistochemistry. Results: Allelic deletions of AXIN1 gene were found in $21.1 \%$ of meningiomas. Microsatellite instability was also observed in $5.3 \%$ of cases. Weak or lack of AXIN1 expression was found in $21.9 \%$ of meningiomas. We found strong statistical correlations between cytoplasmic localization of AXIN1 and its weak expression and also between the simultaneous cytoplasmic and nuclear localizations and moderate and strong expression levels $(p<0.000)$. The findings on AXIN1 were compared to concomitant expression of APC, beta-catenin and E-cadherin in the same patients by Chi-Square tests and Pearson's correlations. Analysis revealed that AXIN1 genetic changes were significantly associated to lack of the expression of $A P C$ and presence of mutant APC proteins $(p<0.018)$. Moderate and strong cytoplasmic and nuclear AXINI
\end{abstract}

Correspondence to: Nives Pećina-Šlaus, Laboratory of Neurooncology, Croatian Institute for Brain Research, School of Medicine, University of Zagreb, Šalata 12, HR-10000 Zagreb, Croatia. Tel: +385 14621140, Fax: +385 14590199; +385 14920050, e-mail: nina@mef.hr

Key Words: AXIN1, meningiomas, loss of heterozygosity, immunohistochemistry, Wnt signaling. expressions were positively correlated to strong expression of E-cadherin ( $p<0.05)$. Conclusion: Our findings on genetic changes and expression levels of AXIN1 bring novel data on its involvement in meningeal brain tumors and reveal AXINI's relation to specific Wnt molecules.

In the present study we investigated the involvement of AXIN1 in central nervous system (CNS) tumors meningiomas. Research over the last decade recognized the importance of Wnt signaling pathway in the formation and growth of meningiomas (1-4). This study was designed to investigate the loss of heterozygosity and levels of protein expression of AXIN1 gene in intracranial meningiomas, as well as AXIN1's association to other Wnt molecules, APC, beta-catenin and E-cadherin.

Tumor suppressor gene AXIN1, 16p13.3, $96 \mathrm{kDa}$, is a crucial component of Wnt signaling. The original role assigned for AXIN was to serve as the backbone of betacatenin destruction complex and inhibit Wnt signaling acting as negative regulator of the pathway (5-8). Nevertheless, it has been demonstrated that AXIN can be found at the plasma membrane, too. Protein Dishevelled can bind AXIN and direct it to the membrane, but AXIN can also directly bind to the Wnt co-receptors LRP5/6 and form the so called LRP signalosome. When part of the signalosome and AXIN located at the plasma mebrane, AXIN promotes the activation of the signal (9). Novel research indicates its presence in the cell nucleus, too (9-11). Athough at the first two cellular compatments the role of AXIN is mostly understood, its function in the nucleus is still largely unknown.

The best studied is the canonical Wnt signaling also known as beta-catenin pathway discovered in developmental research. Today, we know that this pathway is one of the basic cellular pathways balancing a variety of processes 
including cell proliferation, migration, and differentiation. It is also critical for adult tissue homeostasis, is involved in epithelial to mesenchymal transition and the deregulation of Wnt signaling has been linked to a number of human cancers. The pathway is activated by binding of Wnt ligands to specific receptors named frizzleds $(\mathrm{Fz})(12)$. The signal is subsequently transduced to beta-catenin. Beta-catenin levels rise, and as a consequence it enters the nucleus (13-16), where bound to a transcription cofactor LEF/TCF (lymphoid enhancer factor/ $\mathrm{T}$ cell factor) activates the transcription of target genes encoding for $c-m y c, N-m y c, c-j u n, f r a-1$ and cyclin D1 (15-19).

In healthy normal circumstances beta-catenin is degraded in a multiprotein destructive complex where AXIN acts as the backbone. Thus, the components of beta-catenin destruction complex represent negative regulators of the pathway and the low beta-catenin quantities render this pathway inactive. Besides AXIN, the complex is composed of APC (adenomatous polyposis coli), casein kinase 1 (CK1), glycogen synthase kinase 3 beta (GSK3 $\beta$ ), facilitating phosphorylation, ubiquitination, and proteasomal degradation of beta-catenin (19-21). The activation of Wnt signaling pathway also happens in cases of APC, AXIN and other components of beta-catenin destruction complex are mutated and/or non-functional $(13,15,18,22)$.

There are several reasons why we propose studying AXIN1 in meningiomas. It has long been known that Wnt signaling regulates critical processes of normal CNS development. Processes that include cellular adhesion, synaptic rearrangements, embryonic cell patterning, proliferation, differentiation, and apoptosis require the expression of molecular components of the Wnt pathway. There exists emerging evidence suggesting that AXIN plays critical roles in the regulation of synaptic functions, formation of synaptic protein complexes and anchoring postsynaptic proteins in the central nervous system $(6,23,24)$. Another negative regulator of Wnt signaling, APC, shows high expression in the CNS (25), and is involved in initiation of neuronal differentiation. Moreover, our previous investigations demonstrated the involvement of Wnt signaling molecules-beta-catenin, APC and E-cadherin in meningiomas $(26,27)$. A recent proteomic study also reported on differentially expressed Wnt signaling proteins in meningioma (4). All these findings suggest that the molecular components of Wnt signaling perform important functions in CNS tissues.

Meningiomas, that originate from the arachnoidal cap cells of the leptomeninges account for approximately $30 \%$ of primary intracranial and intraspinal tumors. The majority of meningiomas corresponds to grade I of WHO classification of CNS tumors and thus are benign, slowly growing tumors (28-30) with good prognosis when adequately resected. Atypical meningiomas (WHO grade II) represent approximately $10-15 \%$ of all meningiomas. Unfortunately, there are also $3 \%$ of anaplastic meningiomas (WHO grade III) that will exhibit brain invasion and features of malignant behavior. They are typically associated with brain invasion and recurrence, and the overall 10-year survival rate is low (2). Recurrence rates for atypical meningiomas are $29-52 \%$ and for anaplastic 50-94\%. Thus, it is clinically important to reveal the molecular characteristics of meningioma development and progression. The majority of meningiomas suffer losses on $22 \mathrm{q}$ including loss of heterozygosity of the neurofibromatosis type 2 gene (NF2) (1). Loss of merlin, protein encoded by $N F 2$ is consistent finding in all neurofibromatosis type 2 associated meningiomas and in about half of sporadic benign cases $(31,32)$. Relevant genetic alterations of atypical and anaplastic meningiomas are emerging thanking to high throughput techniques and indicate importance of the Pi3K/Akt/mTOR/pS6RP, Ras/Raf/Mek/Erk, and p53 signaling. Although several molecular studies have examined alterations of many tumor suppressor genes and oncogenes in meningiomas $(33,34)$, the molecular etiology and pathogenesis of intracranial meningiomas still need to be elucidated.

\section{Materials and Methods}

Tumor specimens. Samples of 32 meningiomas together with 32 autologous blood tissues were collected from the Department of Neurosurgery and "Ljudevit Jurak" Department of Pathology, University Hospital "Sisters of Mercy", Zagreb, Croatia. Using magnetic resonance imaging (MRI) tumor lesions were found in different cerebral regions, with the surrounding zone of perifocal oedema. During the operative procedure the tumor was maximally reduced using a microneurosurgical technique. The patients had no family history of brain tumors and did not undergo chemotherapy or radiotherapy prior to surgery. Collected tumor tissues were frozen in liquid nitrogen and transported to the laboratory, where they were immediately transferred at $-75^{\circ} \mathrm{C}$. The peripheral blood samples were collected in EDTA and processed immediately. All tumors were studied by pathologists and classified according to the WHO criteria (29). There were 14 meningothelial meningiomas, 6 fibrous (fibroblastic), 4 transitional (mixed), 1 psammomatous, 3 angiomatous, 2 atypical and 2 anaplastic meningiomas.

Sixteen patients were female, and 16 male. The age of patients varied from 35 to 76 (mean age $=60.4$ years). The mean age at diagnosis for females was 63, and for males 58 years. Ethical approval was received from the Ethical Committees Medical School University of Zagreb and University Hospital "Sisters of Mercy", and the patients gave their informed consent as well.

DNA extraction. Approximately $0.5 \mathrm{~g}$ of tumor tissue was homogenized with $1 \mathrm{ml}$ extraction buffer $(10 \mathrm{mM}$ Tris $\mathrm{HCl} ; 0.1 \mathrm{M}$ EDTA; 0.5\% sodium dodecyl sulfate, $\mathrm{pH}$ 8.0) and incubated with $100 \mathrm{mg} / \mathrm{ml}$ proteinase K (Sigma-Aldrich, St. Louis, MI, USA), overnight at $37^{\circ} \mathrm{C}$. Phenol/chloroform extraction and ethanol precipitation followed. Blood was used to extract leukocyte DNA. Five $\mathrm{ml}$ of blood was lysed with $7 \mathrm{ml}$ distilled water and centrifuged $(15 \mathrm{~min} / 5,000 \times \mathrm{g})$. The pellet was further processed same as for DNA extraction from the tissue samples. 


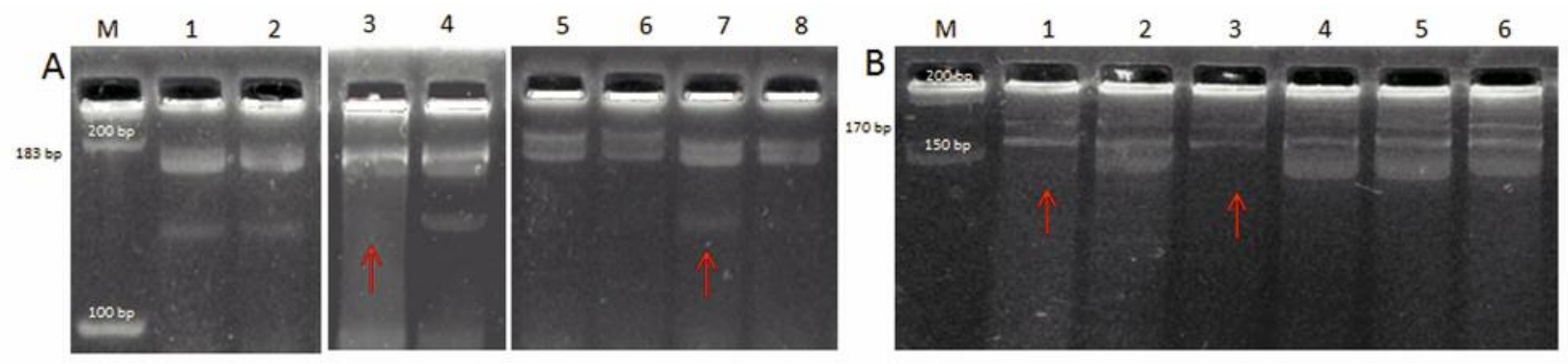

Figure 1. Genomic instabilities, LOH and MSI, of the AXIN1 gene in meningioma samples on Spreadex gels (Elchrom Scientific) stained with SYBR Gold (Molecular Probes). A) Polymorphic marker D16S3399 is shown. Lane M-M3 standard; lanes 1, 3, 5, 7-meningioma samples; lanes 2, 4, 6, 8 -corresponding blood samples; lane 3 - LOH of the AXIN1 gene; lane 7 -sample demonstrating MSI. B) Polymorphic marker D16S3400 is shown. Lane M-M3 standard; lanes 1, 3,5-meningioma samples; lanes 2, 4,6-corresponding blood samples; lanes 1, 3 - LOHs of the AXIN1 gene.

Polymerase chain reaction, loss of heterozygosity and microsatellite instability. Two highly polymorphic microsatellite markers (CA dinucleotide repeats) D16S3399 and D16S3400 linked to the AXIN1 gene were amplified in a volume of $25 \mu \mathrm{l}$ of the following reaction mixture: 5 pmol of each primer, 200-400 ng DNA, $2.5 \mu$ PCR buffer (500 mM KCl, $100 \mathrm{mM}$ Tris-HCl, pH 8.3), $2 \mathrm{mM} \mathrm{MgCl}_{2}, 2.5$ $\mathrm{mM}$ of each dNTP, $5 \mathrm{U} / \mu \mathrm{l}$ Taq polymerase (Promega, Madison, WI, USA). Polymerase chain reaction (PCR) conditions were initial denaturation, $3 \mathrm{~min} / 95^{\circ} \mathrm{C}$; denaturation, $30 \mathrm{~s} / 96^{\circ} \mathrm{C}$; annealing, 30 $\mathrm{s} / 56^{\circ} \mathrm{C}$; extension, $30 \mathrm{~s} / 72^{\circ} \mathrm{C}$ adding 1 extra second after every cycle.; final extension, $10 \mathrm{~min} / 72^{\circ} \mathrm{C} ; 35$ cycles. PCR products were analyzed on $2 \%$ agarose gels and minimal length of repeats was 183 bp for D16S3399 and for D16S3400 170 bp (35).

Primers used for D16\$3399 were: 5'-GGGCCATTATTCA GCCAATC-3' and 5'-ACCTAGATCCCTCCAGGTTT-3'; and for D16S3400: 5'-AGCTGAGATCACGCCATTGC-3' and 5'-TGTG AGGAGACAGGAAAGAG-3',

To discover loss of heterozygosity (LOH) of the AXIN1 in heterozygous patients, samples were visualized on Spreadex EL 400 Mini gels (Elchrom Scientific, ALLabortechnik, AL-Diagnostic $\mathrm{GmbH}$, Amstetten, Austria) stained with SYBR Gold, (Invitrogen, Molecular Probes, Eugene, OR, USA). Absence or significant decrease of one allelic band in the tumor compared to autologous blood sample was considered as LOH of the AXIN1 gene.

Microsatellite instability (MSI) is a type of genomic instability characteristic for tumor cells. Samples demonstrating MSI have bands on different positions in comparison to bands of autologous blood tissue indicating impaired cellular DNA mismatch repair in tumor cells.

Immunohistochemistry. Immunohistochemistry was performed in order to establish the levels of expression and cellular localization of AXIN1 proteins. Tissue samples were fixed and embedded in paraffin, sliced into $4-\mu \mathrm{m}$ thick sections, and then fixed onto capillary gap microscope slides (DakoCytomation, Glostrup, Denmark). Sections were immunostained using streptavidin horseradish peroxidase/DAB (EnVision ${ }^{\mathrm{TM}}$, Dako REAL ${ }^{\mathrm{TM}}$ ). Briefly, sections were deparaffinized and rehydrated and then microwaved twice for $3 \mathrm{~min}$ at $700 \mathrm{~W}$ in citrate buffer and once for $4 \mathrm{~min}$ at 350 $\mathrm{W}$ to unmask epitopes. To block endogenous peroxidase activity, cells were fixed in methanol with $3 \% \mathrm{H}_{2} \mathrm{O}_{2}$ for $10 \mathrm{~min}$. Nonspecific binding was blocked by incubating samples with goat serum for $30 \mathrm{~min}$ at $4^{\circ} \mathrm{C}$. Next, the primary antibodies were applied over night at $4^{\circ} \mathrm{C}$. The antibody used for AXIN1 protein detection was rabbit polyclonal anti-human AXIN1 antibody (Zymed Laboratories, San Francisco, CA, USA) (diluted 1:50).

After incubation, the slides were washed three times in phosphate-buffered saline/goat serum. Secondary LINK antibody was applied for $30 \mathrm{~min}$ at $4^{\circ} \mathrm{C}$. Slides were again washed three times in $\mathrm{PBS} /$ goat serum and were incubated with substrate chromogen solution (EnVisionTM, Dako REAL ${ }^{\mathrm{TM}}$ ) for $30 \mathrm{sec}$.

Negative controls underwent the same staining procedure but without incubating samples with the primary antibodies. Cortex of the frontal part of the normal brain, normal skin and lymph node tissues served as positive internal controls. Antibody labeling was analyzed by three independent and blinded observers using an Olympus BH-2 microscope. No expression or very weak expression was labeled as $0 /+$, moderate expression as ++ , and strong expression as +++. Additionally, two hundred cells of each sample were analyzed for different expression levels.

Statistical analysis. All individuals were analyzed for the following features: meningioma histological subtype, malignancy grade, sex, age, AXIN1 genetic changes, protein expression intensities, subcellular localization and number of cells showing specific intensity, APC, E-cadherin and beta-catenin status in relation to AXIN1 values. Differences in the values of AXIN1 expressions (strong, moderate, weak) were tested with Chi-Square tests and Pearson's correlations were also used to assess relationships between the various paramethers. Statistical significance was set at $p<0.05$. All statistical evaluations were performed with the SPSS statistical package 14.0 (SPSS Inc., Chicago, IL, USA).

\section{Results}

The results of our analysis showed that out of 23 meningiomas that were available for genetic analysis, $82.6 \%$ were informative when analyzed with both polymorphic dinucleotide markers, D16S3399 and D16S3400. Loss of heterozygosity $(\mathrm{LOH})$ revealing gross deletions of AXIN1 gene was observed in $21.1 \%$ of total informative tumors. Another type of genetic alteration inherent for cancer cellsMSI, was also observed in $5.3 \%$ of meningioma sample. LOHs of AXIN1 gene are shown in Figure 1. 
Next, we analyzed AXIN1 expression levels in 32 meningioma cases. Immunohistochemical method revealed localization and quantity of AXIN1 protein. Expression levels of AXIN1 were compared to the frontal part of the non-tumorous brain, skin and lymph node that served as positive controls. The expression of AXIN1 was found present in the majority of the analyzed samples and heterogeneously distributed throughout the tumors with predominant cytoplasmic and nuclear localizations. AXIN1 was observed exclusively in the cytoplasm in $25 \%$ of samples, and in both the cytoplasm and nucleus in $75 \%$ samples of meningeoma brain tumors. Immunostaining of AXIN1 proteins is demonstrated in (Figure 2A-D). The results on AXIN1 genetic changes and protein expression levels together with demographic data and histological subtypes are presented in Table I.

The staining intensity of 200 cells per sample in the hot spot (an area containing the most characteristics of malignant tissue) was analyzed. Samples were then categorized according to the proportion of cells with a specific staining intensity which reflects the level of expression of AXIN1 protein (Figure 3).

Seven out of 32 cases $(21.9 \%)$ demonstrated negative or very weak AXIN1 expression levels (lower than the levels measured in positive controls). Such expression levels were localized solely in the cytoplasm and only one sample with cytoplasmic staining had moderate expression. This indicates down-regulation of this tumor suppressor gene when compared to the levels of axin in healthy brain tissues. All the other samples had AXIN1 localized in both the cytoplasm and nucleus with moderate and/or strong expression. Moderate expression was noted in $34.4 \%$ of our total samples and strong in $43.8 \%$ corresponding to AXIN1 protein expression levels observed in normal tissues.

We also noted that the samples with moderate cytoplasmic expression had a lower number of counted cells with nuclear AXIN1 staining (mean $13.5 \%$ of cells) than the samples with strong cytoplasmic expression. The percent of samples with strong cytoplasmatic staining that were also accompanied with strong nuclear staining was 64.3 (9/14). The average number of cells demonstrating strong nuclear staining was lower than the number of cells with strong cytoplasmic staining.

Additional statistical analyses were performed in order to establish relevant correlations of the obtained results. First we correlated the roughly estimated intensities of expressed AXIN1 and subcellular localizations and found strong statistical correlation between cytoplasmic localization of AXIN1 to weak expression of this protein. Moreover, AXIN1 localization in both cytoplasm and nucleus was strongly correlated to moderate and strong AXIN1 expression levels (Pearson's Chi square $=26.984$, Pearson's correlation 0.834, $p<0.000$ ) (Table II). When we performed more detailed statistical analysis and included the number of counted cells with different expression levels, again statistically significant correlation emerged confirming first tests. Strong correlation coefficient indicated that AXIN1 protein levels characterized as weak expression were present in significantly higher number of counted cells with cytoplasmic expression only (Pearson's Chi square $=18.000$, Pearson's correlation $=-0.995$, $p<0.000$ ) (Table III). Consistently, strong and moderate expression levels were noted in higher number of cells with cytoplasmic and nuclear localizations.

We also analyzed the expression of AXIN1 in relation to the pathohistological classification of meningiomas. Due to a small number of cases in certain meningioma subtypes, AXIN1 genetic changes were not associated to specific pathohistological (PHD) grade. Nevertheless, AXIN1 expression levels presented differences among analyzed histologic variants. Down-regulation of AXIN1 expression was statistically different among the analyzed PHD subtypes (Chi square $=11,241 ; p=0.047$ ). Fibrous meningioma exhibited the highest frequency of down-regulated AXIN1, while the remaining subtypes generally exhibited higher frequencies of normal strong expression.

Since misregulation of signaling pathways relies on intrinsic molecular dependancies, we decided to investigate how data obtained on AXIN1 in the present experimental work relate to our previous findings on meningiomas regarding APC, Ecadherin and beta-catenin $(26,27)$. Therefore, we correlated all the assesed variables anew. The results of this analysis demonstrate that the association between levels and localizations of AXIN1 expression were not statistically correlated to APC protein levels, nor its genetic changes. Contrary to this, there was statistically strong correlation of AXIN1 genetic changes to APC protein expression (Pearson's Chi square $=5.647$, Pearson's correlation 0.537, $p<0.018$ ). LOH of AXINl was associated to lack of expression of APC or presence of mutant APC proteins (Table IV). Although not significant, a trend was observed $(p=0.07)$ between samples with LOHs of APC gene and those without LOH of AXIN1.

We also found a positive correlation between the intensities of AXIN1 and E-cadherin protein expressions. Moderate and strong cytoplasmic and nuclear expression of AXIN1 was positively correlated to strong expression of Ecadherin (Pearson's Chi square $=4.426$, Pearson's correlation $0.350, p<0.05$ ) (Table V). We were unable to establish statistically significant correlation between beta-catenin and AXIN1 expression levels, but noticed that in samples with strong or moderate AXIN1 expression the levels of betacatenin were in the category of low levels in $41 \%$ of cases.

\section{Discussion}

The study of Wnt signaling pathway in a variety of tumor tissues over the past three decades has revealed an extensive, yet still incomplete, set of genes and proteins playing minor 

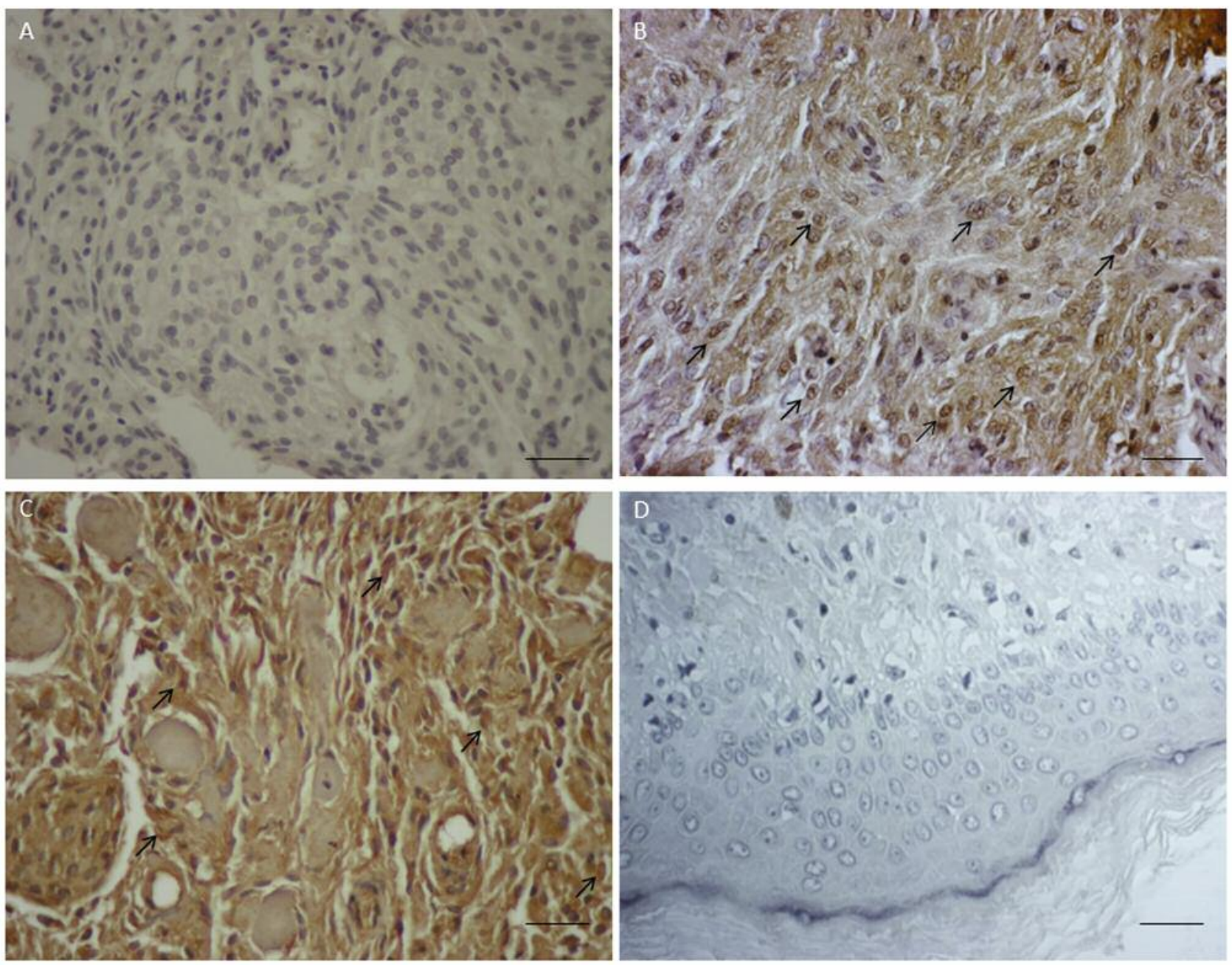

Figure 2. Meningioma samples immunohistochemically stained for the expression of AXIN1 proteins demonstrating categories of weak 0/+ $(A)$, moderate $++(B)$ and strong $+++(C)$ expression of AXIN1. Several cells with nuclear expressions are indicated by arrows. Negative control staining (D). Original magnification $400 \times$, scale bar $50 \mu \mathrm{m}$.

\section{A) Localization and levels of expression in meningiomas}

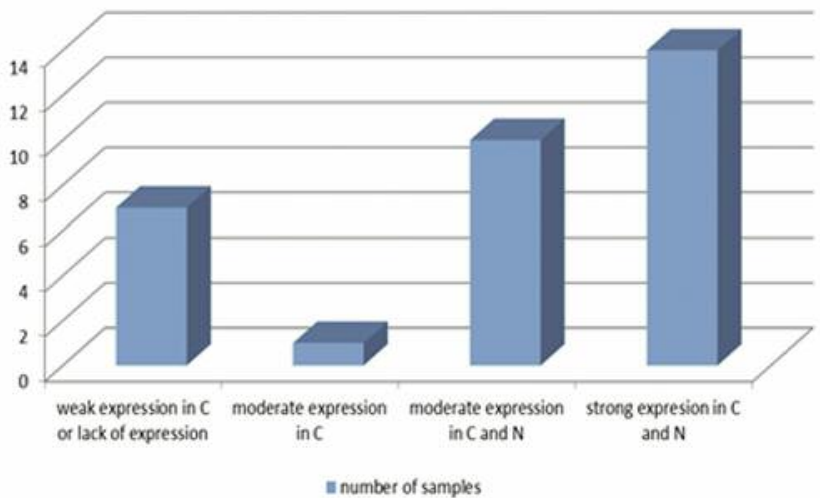

B) Intensity of staining in total number of counted cells

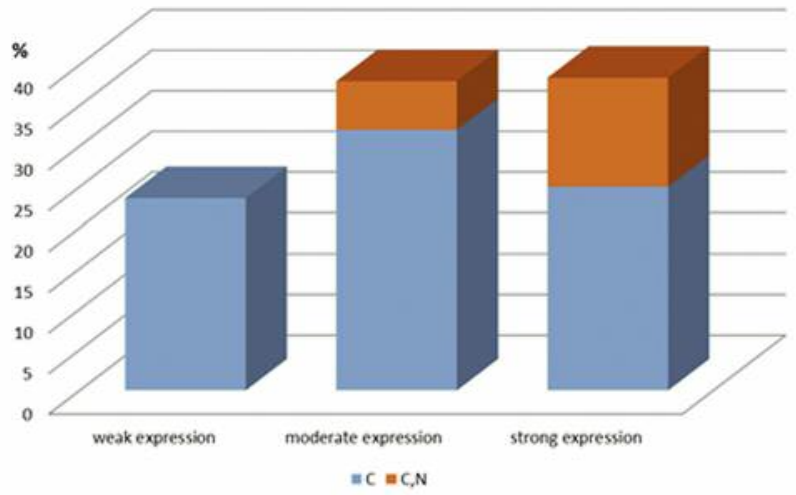

Figure 3. Localization and levels of expression of AXIN1 in meningioma (A). The percent of total number of counted cells displaying specific staining intensities in cytoplasm and nucleus $(B)$. 
Table I. Pathohistological subtype, demographic variables, the polymorphic status for D16S3399 and D16S3400 markers, genetic changes of AXIN1 gene, expression levels and localizations of AXIN1 proteins.

\begin{tabular}{|c|c|c|c|c|c|}
\hline $\begin{array}{l}\text { Pat. } \\
\text { No. }\end{array}$ & $\begin{array}{c}\text { Patho-histological } \\
\text { diagnosis }\end{array}$ & Gender & Age & $\begin{array}{c}A X I N-1 \\
\text { D16S3399 } \\
\text { D16S3400 }\end{array}$ & $\begin{array}{c}\text { AXIN-1 } \\
\text { Expression/percent of } \\
\text { counted cells }\end{array}$ \\
\hline
\end{tabular}

\begin{tabular}{|c|c|c|c|c|c|}
\hline 1 & Meningothelial & M & 72 & HETERO & $\mathrm{C}+++(85 \%) ; \mathrm{CN}+++(15 \%)$ \\
\hline 2 & Meningothelial & M & 68 & ND & $\mathrm{C}+(100 \%)$ \\
\hline 3 & Meningothelial & $\mathrm{F}$ & 70 & MSI & $\mathrm{C}+++(91,5 \%) ; \mathrm{CN}+++(8,5 \%)$ \\
\hline 4 & Meningothelial $^{\mathrm{NF} 2 \mathrm{LOH}}$ & $\mathrm{F}$ & 62 & $\mathrm{LOH}$ & $\mathrm{C}++(94 \%) ; \mathrm{CN}++(6 \%)$ \\
\hline 5 & Meningothelial Dur & M & 64 & HETERO & $\mathrm{C}++(79 \%) ; \mathrm{CN}++(21 \%)$ \\
\hline 6 & Meningothelial & M & 65 & HETERO & $\mathrm{C}+++(66,3 \%) ; \mathrm{CN}+++(33,7 \%)$ \\
\hline 7 & Meningothelial & M & 35 & $\mathrm{LOH}$ & $\mathrm{C}++(84,2 \%) ; \mathrm{CN}++(15,8 \%)$ \\
\hline 8 & Meningothelial & $\mathrm{F}$ & 55 & $\mathrm{LOH}$ & $\mathrm{C}+++(94 \%) ; \mathrm{CN}++(6 \%)$ \\
\hline 9 & Meningothelial & $\mathrm{F}$ & 47 & ND & $\mathrm{C}++(86 \%) ; \mathrm{CN}++(14 \%)$ \\
\hline 10 & Meningothelial ${ }^{\text {Bon }}$ & M & 70 & HOMO & $\mathrm{C}+++(68 \%) ; \mathrm{CN}+++(32 \%)$ \\
\hline 11 & Meningothelial Rec & M & 54 & HOMO & $\mathrm{C}+(57,5 \%) ; \mathrm{C}++(26,5 \%) ; \mathrm{CN}++(16 \%)$ \\
\hline 12 & Meningothelial & $\mathrm{F}$ & 69 & HOMO & $\mathrm{C}+(100 \%)$ \\
\hline 13 & Meningothelial & M & 52 & ND & $\mathrm{C}+++(49,5 \%) ; \mathrm{CN}+++(50,5 \%)$ \\
\hline 14 & 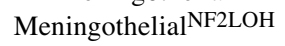 & $\mathrm{F}$ & 70 & HETERO & $\mathrm{C}++(88,5 \%) ; \mathrm{CN}++(11,5 \%)$ \\
\hline 15 & Fibrous (fibroblastic) & M & 54 & HETERO & $\mathrm{C}++(83,5 \%) ; \mathrm{CN}++(16,5 \%)$ \\
\hline 16 & Fibrous (fibroblastic) & $\mathrm{F}$ & 63 & HETERO & $\mathrm{C}+(100 \%)$ \\
\hline 17 & Fibrous (fibroblastic) & $\mathrm{F}$ & 63 & HETERO & 0 \\
\hline 18 & Fibrous (fibroblastic) & M & 45 & HETERO & 0 \\
\hline 19 & Fibrous (fibroblastic) & $\mathrm{F}$ & 51 & HETERO & $\mathrm{C}++(47 \%) ; \mathrm{CN}+++(53 \%)$ \\
\hline 20 & Fibrous (fibroblastic) & $\mathrm{F}$ & 73 & HETERO & $\mathrm{C}+(100 \%)$ \\
\hline 21 & Transitional (mixed) & $\mathrm{F}$ & 56 & $\mathrm{LOH}$ & $\mathrm{C}++(100 \%)$ \\
\hline 22 & Transitional (mixed) & $\mathrm{M}$ & 61 & ND & $\mathrm{C}+++(75 \%) ; \mathrm{CN}++(25 \%)$ \\
\hline 23 & Transitional (mixed) & M & 45 & ND & $\mathrm{C}+++(26 \%) ; \mathrm{CN}+++(74 \%)$ \\
\hline 24 & Transitional(mixed) Dur & $\mathrm{F}$ & 50 & ND & $\mathrm{C}+++(88 \%) ; \mathrm{CN}+++(12 \%)$ \\
\hline 25 & Psammomatous & $\mathrm{F}$ & 60 & ND & $\mathrm{C}++(87,5 \%) ; \mathrm{CN}++(12,5 \%)$ \\
\hline 26 & Angiomatous & M & 66 & HETERO & $\mathrm{C}+++(54 \%) ; \mathrm{CN}+++(46 \%)$ \\
\hline 27 & Angiomatous & M & 39 & HETERO & $\mathrm{C}+++(74 \%) ; \mathrm{CN}+++(26 \%)$ \\
\hline 28 & Angiomatous & $\mathrm{F}$ & 70 & ND & $\mathrm{C}++(50,7 \%) ; \mathrm{CN}+++(49,3 \%)$ \\
\hline 29 & Atypical & M & 76 & HOMO & $\mathrm{C}++(36 \%) ; \mathrm{C}+++(31,5 \%) \mathrm{CN}++(32,5 \%)$ \\
\hline 30 & Atypical & M & 56 & ND & $\mathrm{C}++(87,5 \%) ; \mathrm{CN}++(12,5 \%)$ \\
\hline 31 & Anaplastic (malignant) & $\mathrm{F}$ & 71 & HETERO & $\mathrm{C}+(100 \%)$ \\
\hline 32 & Anaplastic (malignant) & $\mathrm{F}$ & 69 & HETERO & $\mathrm{C}++(90,5 \%) ; \mathrm{CN}++(9,5 \%)$ \\
\hline
\end{tabular}

LOH, Loss of heterozygosity; MSI, microsatellite instability; HETERO, heterozygous samples; HOMO, homozygous uninformative samples; ND, not determined; Durdura invasion; Bonbone invasion; Rec recurrence; C, cytoplasm; N, nucleus; +=intensities of immunostain; 0=negative ; patients from no. 1 to 28 are malignancy grade I; patients no. 29, 30 are grade II; patients no. 31, 32 are grade III.

and major roles. In this complex signaling network AXIN1, named for its role in the inhibition of vertebrate axis formation during embryonic development, is an interesting and curious molecule being characterized as a scaffold protein and a tumor suppressor. By studying the dysregulation of Wnt pathway, which has been found to play important role in development and progression of various tumors, we attempted to identify a small segment of molecular events governing meningioma tumorigenesis.

Our findings on AXINI LOHs, MSI and expression levels bring novel reports on AXIN1 involvement in meningeal brain tumors so far not reported in the literature. Genetic changes found in our study comprized of gross deletions of AXIN1 gene in $21.1 \%$ of informative tumors. This finding could indicate AXINI's classical behavior as tumor suppressor and suggest consequent down-regulation of its protein. However, $75 \%$ of our patients who harboured $\mathrm{LOH}$ of AXIN1 gene showed moderate AXIN1 protein expression levels. It seems that allelic deletions are not sufficient for AXINl's major expression down-regulation. Since AXIN is frequently mutated in several investigated cancers, inactivating point-mutations could be held responsible, as well as other types of mechanisms for the regulation of gene expression, like promoter hypermethylation (9).

It is a well-known fact that subsets of meningiomas contain microsatellite instability (MSI) in low frequencies $(36,37)$. In the present study we found $5.3 \%$ of meningiomas with MSI. In a previous study on E-cadherin 
Table II. Comparison of values of expression of AXIN1 protein and its localization.

\begin{tabular}{lccc}
\hline & \multicolumn{3}{c}{ Chi-Square Tests } \\
\cline { 2 - 4 } & Value & df & Asymp.Sig.(2-sided) \\
\hline Pearson Chi-Square & $26.984^{\mathrm{a}}$ & 3 & 0.000 \\
Likelihood Ratio & 27.879 & 3 & 0.000 \\
Linear-by-Linear Association & 21.551 & 1 & 0.000 \\
N of Valid Cases & 32 & & \\
\hline
\end{tabular}

aFive cells $(62.5 \%)$ have expected count less than 5 . The minimum expected count is 0.22 .

\begin{tabular}{lcc}
\hline & \multicolumn{2}{c}{ Correlations } \\
\cline { 2 - 3 } & AXIN1 protein & AXIN1 localization \\
\hline AXIN1 protein & 1 & $0.834^{* *}$ \\
$\quad$ Pearson correlation & 32 & 0.000 \\
Sig. (2-tailed) & & 32 \\
N & $0.834^{* *}$ & 1 \\
AXIN1 localization & 0.000 & 32 \\
Pearson correlation & 32 & \\
Sig. (2-tailed) & & \\
N & & \\
\hline
\end{tabular}

**Correlation is significant at the 0.01 level (2-tailed).

Table III. Comparison of values of AXIN1 protein and number of counted cells with weak expression.

\begin{tabular}{|c|c|c|c|}
\hline & \multicolumn{3}{|c|}{ Chi-Square Tests } \\
\hline & Value & df & Asymp.Sig.(2-sided) \\
\hline Pearson Chi-Square & $18.000^{\mathrm{a}}$ & 6 & 0.006 \\
\hline Likelihood Ratio & 12.307 & 6 & 0.055 \\
\hline Linear-by-Linear Association & 7.918 & 1 & 0.005 \\
\hline $\mathrm{N}$ of Valid Cases & 9 & & \\
\hline \multicolumn{4}{|c|}{$\begin{array}{l}\text { a } 12 \text { cells }(100.0 \%) \text { have expected count less than } 5 \text {. The minimum } \\
\text { expected count is } 0.11 \text {. }\end{array}$} \\
\hline & \multicolumn{3}{|c|}{ Correlations } \\
\hline & & IN1 & $\begin{array}{c}\text { No of cells with } \\
\text { weak or lack } \\
\text { of expression }\end{array}$ \\
\hline \multicolumn{4}{|l|}{ AXIN1 protein } \\
\hline Pearson correlation & & 1 & $-0.995 * *$ \\
\hline Sig. (2-tailed) & & & 0.000 \\
\hline $\mathrm{N}$ & & 32 & 9 \\
\hline \multicolumn{4}{|c|}{ No of cells with weak expression } \\
\hline Pearson correlation & & $95^{* *}$ & 1 \\
\hline Sig. (2-tailed) & & 000 & \\
\hline $\mathrm{N}$ & & 9 & 9 \\
\hline
\end{tabular}

**Correlation is significant at the 0.01 level (2-tailed).
Table IV. Comparison of values of AXIN1 genetic changes and APC protein expression.

\begin{tabular}{lccc}
\hline & \multicolumn{3}{c}{ Chi-Square Tests } \\
\cline { 2 - 4 } & Value & df & Asymp.Sig.(2-sided) \\
\hline Pearson Chi-Square & $5.647 \mathrm{a}$ & 2 & 0.059 \\
Likelihood Ratio & 5.961 & 2 & 0.051 \\
Linear-by-Linear Association & 5.189 & 1 & 0.023 \\
N of Valid Cases & 19 & & \\
\hline
\end{tabular}

aFour cells (66.7\%) have expected count less than 5. The minimum expected count is 0.37 .

\begin{tabular}{lcc}
\hline & \multicolumn{2}{c}{ Correlations } \\
\cline { 2 - 3 } & AXIN1 gene & APC protein \\
\hline AXIN1 gene & 1 & $0.537^{* *}$ \\
$\quad$ Pearson correlation & 19 & 0.018 \\
Sig. (2-tailed) & & 19 \\
$\mathrm{~N}$ & $0.537^{* *}$ & 1 \\
APC protein & 0.018 & 33 \\
Pearson correlation & 19 & \\
Sig. (2-tailed) & & \\
$\mathrm{N}$ & & \\
\hline
\end{tabular}

**Correlation is significant at the 0.05 level (2-tailed).

Table V. Comparison of values of expression of AXIN1 and E-cadherin proteins.

\begin{tabular}{lccc}
\hline & \multicolumn{3}{c}{ Chi-Square Tests } \\
\cline { 2 - 4 } & Value & df & Asymp.Sig.(2-sided) \\
\hline Pearson Chi-Square & $4.426^{\mathrm{a}}$ & 3 & 0.219 \\
Likelihood Ratio & 5.134 & 3 & 0.162 \\
Linear-by-Linear Association & 3.797 & 1 & 0.051 \\
N of Valid Cases & 32 & & \\
\hline
\end{tabular}

aFive cells $(62.5 \%)$ have expected count less than 5 . The minimum expected count is 0.4 .

\begin{tabular}{lcc}
\hline & \multicolumn{2}{c}{ Correlations } \\
\cline { 2 - 3 } & AXIN1 protein & E-cadherin protein \\
\hline AXIN1 protein & 1 & $0.350^{*}$ \\
$\quad$ Pearson correlation & 32 & 0.050 \\
Sig. (2-tailed) & & 32 \\
$\mathrm{~N}$ & $0.350^{*}$ & 1 \\
E-cadherin protein & 0.050 & 33 \\
Pearson correlation & 32 & \\
Sig. (2-tailed) & & \\
$\mathrm{N}$ &
\end{tabular}

*Correlation is significant at the 0.05 level (2-tailed). 
employing microsatellite marker D16S752, our group also detected genomic instability in $11 \%$ of meningiomas (27). MSI-positive samples may be indicative of malfunctioning of replication/repair genes and DNA mismatch repair mechanisms which would allow the increase of mutational frequency and the accumulation of many mutations.

Bearing in mind the known function and proposed activities, AXIN1 is expected to be located in the cytoplasm of normal cells where it promotes beta-catenin phosphorylation and degradation. Nevertheless, AXIN1 has been known to shuttle from cytoplasm to the nucleus and nowadays it is considered as a dinamic shuttling protein $(9,11,38)$. Cell staining of AXIN1 in colorectal cancer revealed that AXIN1 can be located diffusely within the nucleus and along lateral cell membranes where beta-catenin is located, and also in the cytoplasm where both GSK3beta and the cytoplasmic pool of beta-catenin are found $(8,39)$. Based on this evidence it is obvious that AXIN1 can shuttle between the cytoplasm and the nucleus and act as a beta-catenin accompanist. On the other hand AXIN can be also found at the membrane where it promotes Wnt signaling as part of LRP signalosome.

The results of our study showed that the majority of investigated meningiomas showed moderate or strong AXIN1 expression (78.2\%). We found strong statistical correlations between cytoplasmic localization of AXIN1 and weak expression of this protein, while cytoplasmic and nuclear localizations were strongly correlated to its moderate and strong expression levels $(p<0.000)$. AXIN's role in the nucleus remains elusive. One theory suggests that APC and AXIN1 are important for the export of beta-catenin from nucleus to the cytoplasm $(40,41)$ functioning as salvage mechanism for betacatenin nuclear removal. Our results on strong cytoplasmatic accompanied with strong nuclear expression levels are in accordance to the findings on AXIN's salvage mechanism.

When we investigated the relationship between AXIN1 expression levels and its subcellular localization in more detail including the number of counted cells statistically significant correlations emerged confirming once again that the levels of expression were significantly differently distributed in different subcellular localizations. Significantly higher number of counted cells showed weak levels of AXIN1 expression when located in cytoplasm $(p<0.000)$. We also noted that the samples with moderate cytoplasmic expression had lower number of cells with nuclear staining of AXIN1 than the samples with strong cytoplasmic expression. Samples with strong cytoplasmatic staining were accompanied with strong nuclear staining in the majority of patients. These findings indicate the AXIN1 activity in meningioma cells happens both in the cytoplasm and nucleus which is consistent to both its roles; as a component of destruction complex and as a nuclear shuttling protein.

The newly-performed analyses on AXIN relations to other Wnt molecular components showed interesting associations.
Firstly, we observed significant correlation of LOH of AXIN1 to the lack of APC protein expression or presence of mutant APC proteins $(p<0.018)$. This is hard to interpret. It may indicate that in cases where $\mathrm{LOH}$ is a mechanism for gene inactivation, at least one of the Wnt pathway members is affected. If $A P C$ is deactivated, there's a less stringent selection for inactivation of it's partner AXIN1 and vice versa. Both associations may point to dissociation of betacatenin destruction complex. Changes of different components of beta-catenin destruction complex have been shown to be mutually exclusive (13) and our findings that AXIN1 and APC protein levels were not significantly correlated may indicate the same pattern. Furthermore, it has been shown that APC plays a role in AXIN destabilization and negative regulation of the basal levels of AXIN independently of Wnt stimulation (11).

We also established a statistically relevant positive correlation between the intensities of AXIN1 and E-cadherin protein expression. Moderate and strong cytoplasmic and nuclear AXIN1 expression was positively correlated to strong expression of E-cadherin $(p<0.05)$. This may be explained by normal morphology and cellular architecture where E-cadherin is holding part of beta-catenin cellular pool in adherens junctions and axin is working properly in destructing beta-catenin $(16,42)$. The correlation between beta-catenin to AXIN1 expression levels was not found to be statistically significant, but we noticed that in $41 \%$ of samples showing strong or moderate AXIN1 expression, beta-catenin was in the cathegory of low expression levels. According to normal functioning of beta-catenin destruction complex this finding is logical.

It is relevant to the present work to discuss the findings of our previous investigations $(26,27)$. We found beta-catenin's up-regulation and nuclear localization in $60 \%$ of anaplastic meningiomas. Moreover, beta-catenin was progressively upregulated from meningothelial to atypical meningiomas. In accordance to our findings is a study by Wrobel et al. (43) who reported on increased expression of beta-catenin and cyclin D1 in meningiomas they have examined by microarray. Besides beta-catenin, we also investigated APC and showed that $47 \%$ of meningiomas harbored allelic losses of this gene. Samples demonstrating allelic losses were significantly accompanied to the lack of protein expression or presence of mutant APC proteins $(p<0.001)$. Observed LOHs of APC were also significantly associated to patients with nuclear localization of beta-catenin protein $(p<0.0001)$. The study on E-cadherin showed LOH of its gene in $32 \%$ of meningiomas and down-regulation of the protein in $56 \%$ of samples. There was also a significant association between the genetic changes of $C D H 1$ and the nuclear localization of beta-catenin protein $(p<0.022)$. Our findings collectively demonstrate that impaired Wnt signaling plays a role in meningiomas, AXIN1 showing a bit lower percentage of 
Table VI. Wnt signaling in meningioma.

\begin{tabular}{|c|c|c|c|}
\hline Gene & Product & Changes in meningioma & Key publications \\
\hline$F R Z B(S F R P 3)$ & Secreted frizzled-related protein 3 & Up-regualtion & (3) \\
\hline SFRP1 & Secreted frizzled-related protein 1 & Down-regulation, up-regulation & $(2,3,43,61,62,63)$ \\
\hline$F Z D 2$ & Frizzled class receptor 2 & Up-regualtion & $(64)$ \\
\hline FZD7 & Frizzled class receptor 7 & Up-regualtion & $(2,3)$ \\
\hline$A P C$ & Adenomatous polyposis coli & Loss of heterozygosity & (26) \\
\hline AXIN1 & Axin 1 & $\begin{array}{c}\text { Gross deletions, down-regulation, } \\
\text { MSI }\end{array}$ & $(24,38)$ \\
\hline$C T N N B 1$ & $\beta$-catenin & Up-regulation & $(2,43,65-68)$ \\
\hline$T C F 3$ & Transcription factor 3 ( $\mathrm{T}$ cell factor 3 ) & Up-regualtion & $(2,3)$ \\
\hline CCND1 & Cyclin D1 & Up-regulation & $(43,61)$ \\
\hline $\mathrm{CDH} 1$ & E-cadherin & $\begin{array}{l}\text { Down-regulation, loss of function, } \\
\text { Gross deletion, MSI }\end{array}$ & $(2,27,42,64,69-71)$ \\
\hline$N D R G 2$ & $\mathrm{~N}$-myc downstream regulator 2 & Down-regulation, promoter hypermetilation & $(1,72-74)$ \\
\hline$C D K 5 R 1$ & Cyclin-dependent kinase 5 , regulatory subunit 1 & Up-regulation & $(2,43)$ \\
\hline CSNK1A1 & Casein kinase 1 , alpha 1 & Up-regulation & (4) \\
\hline
\end{tabular}

changes (allelic deletion found in $21.1 \%$ of meningiomas; expression lost in $21.9 \%$ ) but still behaving in accordance with our findings on other Wnt components.

Novel research has demonstrated that different molecules can modulate AXIN's activity in the Wnt signaling $(9,11)$. The levels of AXIN stability is another important question, raised in part by our study too. Polymerization of AXIN has also been indicated as another mechanism involved in the regulation of its activity. Moreover, Song et al. (9) propose that structural conformational changes determine AXIN's association with other molecules resulting in changes of its activity.

Since detailed literature search did not result in finding papers dealing with the role of AXIN1 in meningioma, we present an overview of studies on AXIN1 in other brain tumors. da Silva et al. (41) found AXIN1 overexpression by QT-PCR in $39.0 \%$ of medulloblastoma cases when compared to normal cerebellum tissue. They also report on higher betacatenin expression in $43.9 \%$ of medulloblastomas and APC's overexpression in $34.1 \%$. Beta-catenin presented differences in relative expression between the large-cell and classic variants $(p<0.05)$ and also between the large-cell and desmoplastic extensive nodularity variants $(p<0.0005)$, whereas the APC and AXIN1 relative expression levels did not differ among the three medulloblastoma groups they analyzed.

Dahmen et al. (44) found one somatic point mutation in exon 1 (Pro255Ser) and seven large deletions (12\%) of AXIN1 gene in 86 medulloblastoma cases and 11 cell lines. Using SSCP analysis and direct DNA sequencing Beaza et al. (45) found missence AXIN1 mutations in 5\% of medulloblastomas. Mutations were located in the APC binding region of the AXIN1 gene. They also reported several AXIN1 polymorphisms. There are also several papers on AXIN in glial tumors. A study by Zhang et al. (46) indicate that AXIN plays an important role in the progression of astrocytoma and may provide useful information for estimating their malignancy. They found that AXIN1 expression was significantly inversely correlated with the grades of astrocytoma $(p<0.05)$ and $34.4 \%$ of astrocytomas showed positive AXIN1 expression. Identification of gross deletions of AXIN1 in $6.3 \%$ of glioblastomas was also reported by our group (10). A study by Lu et al. (47) also demonstrated an important role for AXIN in glioma cell lines.

The collective results of many investigation demonstrate mutations and reduced expression of AXIN1 in different forms of cancer, such as colorectal $(8,48-50)$, hepatocellular $(51,52)$, gastric $(53)$, prostate $(54)$, ovarian endometroid adenocarcinoma (55), lung cancer (56), oesophageal squamous cell carcinoma (57), adrenocortical carcinoma (58) and oral squamous cell carcinoma (59). Mutations were found in the majority of AXIN's domains including APC and beta-catenin binding domains. In contrast to that, AXIN1 mutations were not found in pituitary adenomas (60).

The biological spectrum of meningiomas is heterogeneous and clinical behavior depends on molecular alterations that are also showing great heterogeneity among different subtypes. Even histologically benign meningiomas can recur unexpectedly and start invading surrounding tissues. Therefore, novel revisions of meningioma classification (34) recommend caution on meningioma prognosis. Molecular events driving meningioma progression still need elucidation. The main concerns are meningiomas associated with less favourable clinical outcome.

Several studies (61-74) indicated the importance of Wnt signaling in meningioma. In Table VI key findings and publications on the topic of wnt/E-cadherin and meningioma are presented. 
Our findings on AXIN1 subcellular expression levels and genetic changes and its concomitant expression with different Wnt signaling molecules in the same patients revealed their mutual relation and suggest a role of AXIN1 in a portion of meningiomas. Further analysis on a larger number of histological subtypes is needed to elucidate its biological and clinical relevance.

\section{Conflicts of Interest}

The Authors declare no conflicts of interests.

\section{Acknowledgements}

This work was supported by grant no. 6625 from Croatian Science Foundation.

\section{References}

1 Mawrin C and Perry A: Pathological classification and molecular genetics of meningiomas. J Neurooncol 99: 379-391, 2010.

2 He S, Pham MH, Pease M, Zada G, Giannotta SL, Wang K and Mack WJ: A review of epigenetic and gene expression alterations associated with intracranial meningiomas. Neurosurg Focus 35: E5, 2013.

3 Chang X, Shi L, Gao F, Russin J, Zeng L, He S, Chen TC, Giannotta SL, Weisenberger DJ, Zada G, Wang K and Mack WJ: Genomic and transcriptome analysis revealing an oncogenic functional module in meningiomas. Neurosurg Focus 35: E3, 2013

4 Sharma S, Ray S, Mukherjee S, Moiyadi A, Sridhar E and Srivastava S: Multiprolonged quantitative proteomic analyses indicate modulation of various signal transduction pathways in human meningiomas. Proteomics 15: 394-407, 2015.

5 Clevers H. Wnt breakers in colon cancer. Cancer Cell 5: 5-6, 2004.

6 Luo W and Lin SC: Axin: a master scaffold for multiple signaling pathways. Neurosignals 13: 99-113, 2004.

7 Luo W, Zou H, Jin L, Lin S, Li Q, Ye Z, Rui H and Lin SC: Axin contains three separable domains that confer intramolecular, homodimeric, and heterodimeric interactions involved in distinct functions. J Biol Chem 280: 5054-5060, 2005.

8 Salahshor S and Woodgett JR: The links between axin and carcinogenesis. J Clin Path 58: 225-236, 2005.

9 Song X, Wang S and Li L: New insights into the regulation of Axin function in canonical Wnt signaling pathway. Protein Cell 5: 186-193, 2014

10 Nikuseva Martić T, Pecina-Slaus N, Kusec V, Kokotović T, Musinović H, Tomas D and Zeljko M: Changes of AXIN-1 and beta-catenin in neuroepithelial brain tumors. Pathol Oncol Res 16: 75-79, 2010.

11 Wang Z, Tacchelly-Benites O, Yang E, Thorne CA, Nojima H, Lee E and Ahmed Y: Wnt/Wingless Pathway Activation Is Promoted by a Critical Threshold of Axin Maintained by the Tumor Suppressor APC and the ADP-Ribose Polymerase Tankyrase. Genetics 203: 269-281, 2016.

12 Wharton KA: Runnin' with the Dvl: Proteins that associate with Dsh/Dvl and their significance to wnt signal transduction. Dev Biol 253: 1-17, 2003.
13 Logan CY and Nusse R: The Wnt signaling pathway in development and disease. Annu Rev Cell Dev Biol 20: 781-810, 2004.

14 Gordon MD and Nusse R: Wnt signalling: multiple pathways, multiple receptors, and multiple transcription factors. J Biol Chem 281: 22429-22433, 2006.

15 Polakis P: Wnt signaling in cancer. Cold Spring Harb Perspect Biol 4: a008052, 2012.

16 Fagotto F: Looking beyond the Wnt pathway for the deep nature of $\beta$-catenin. EMBO Rep 14: 422-433, 2013.

$17 \mathrm{Li} \mathrm{F}$, Chong ZZ and Maiese K: Winding through the WNT pathway during cellular development and demise. Histol Histopathol 21: 103-124, 2006.

18 MacDonald BT, Tamai $\mathrm{K}$ and He X: Wnt/ $\beta$-catenin signaling: components, mechanisms, and diseases. Dev Cell 17: 9-26, 2009.

19 Lien W-H and Fuchs E: Wnt some lose some: transcriptional governanace of stem cells by Wnt $/ \beta$-catenin signaling. Genes Dev 28: 1517-1532, 2014.

20 Hart MJ, de los Santos R, Albert IN, Rubinfeld B and Polakis P. Down-regulation of beta-catenin by human Axin and its association with the APC tumor suppressor, beta-catenin and GSK3beta. Curr Biol 8: 573-581, 1998.

21 Cliffe A, Hamada F and Bienz M; A role of Dishevelled in relocating Axin to the plasma membrane during wingless signaling. Curr Biol 13: 960-966, 2003.

22 Kafka A, Bašić-Kinda S and Pećina-Šlaus N: The cellular story of dishevelleds. Croat Med J 55: 459-467, 2014.

23 Fang, WQ, Ip JP, Li R, Ng YP, Lin SC, Chen Y, Fu AK, Ip NY: Cdk5-mediated phosphorylation of Axin directs axon formation during cerebral cortex development. J Neurosci 31: 1361313624, 2011.

24 Chen Y, Fu AKY and Ip NY: Axin: An Emerging Key Scaffold at the Synapse. IUBMB Life 65: 685-691, 2013.

25 Brakeman JS, Gu SH, Wang XB, Dolin G and Baraban JM: Neuronal localization of the Adenomatous polyposis coli tumor suppressor protein. Neuroscience 91: 661-672, 1999.

26 Pećina-Šlaus N, Nikuševa Martić T, Tomas D, Beroš V, Zeljko $\mathrm{M}$ and Čupić H: Meningiomas exhibit loss of Heterosygosity of the APC gene. J Neurooncol 87: 63-70, 2008.

27 Pećina-Šlaus N, Nikuševa Martić T, Deak AJ, Zeljko M and Hrašćan R: Genetic and protein changes of E-cadherin in meningiomas. J Cancer Res Clin Oncol 136: 695-702, 2010.

28 Riemenschneider MJ, Perry A and Reifenberger G: Histological classification and molecular genetics of meningiomas. Lancet Neurol 5: 1045-1054, 2006.

29 Louis DN, Ohgaki H, Wiestler OD, Cavenee WK, Burger PC, Jouvet A, Scheihauer BW and Kleihues P: The 2007 WHO Classification of Tumors of the Central Nervous System. Acta Neuropathol 114: 97-109, 2007.

30 Louis DN, Perry A, Reifenberger G, von Deimling A, FigarellaBranger D, Cavenee WK, Ohgaki H, Wiestler OD, Kleihues P, Ellison DW: The 2016 World Health Organization Classification of Tumors of the Central Nervous System: a summary. Acta Neuropathol 131: 803-820, 2016.

31 Lee JY, Finkelstein S, Hamilton RL, Rekha R, King JT Jr and Omalu B: Loss of heterozygosity analysis of benign, atypical, and anaplastic meningiomas. Neurosurgery 55: 1163-1173, 2004.

32 Fuller CE and Perry A: Molecular Diagnostics in Central Nervous System Tumors. Adv Anat Pathol 12: 180-194, 2005. 
33 Weber RG, Bostrom J, Wolter M Baudis M, Collins VP, Reifenberger $\mathrm{G}$ and Lichter P: Analysis of genomic alterations in benign, atypical, and anaplastic meningiomas: toward a genetic model of meningioma progression. Proc Natl Acad Sci USA 94: 14719-1424, 1997.

34 Fathi AR and Roelcke U: Meningioma. Curr Neurol Neurosci Rep 13: 337, 2013.

35 Kafka A, Musani V, and Pećina-Šlaus N: Optimal amplification conditions for D16S3399 polymorphic STS Axin-1 gene marker. Period Biol 116: 197-199, 2014.

36 Sobrido MJ, Pereira CR, Barros F, Forteza J, Carracedo A and Lema M: Low frequency of replication errors in primary nervous system tumours. J Neurol Neurosurg Psychiatry 69: 369-375, 2000.

37 Simon M, Boström JP and Hartmann C: Molecular genetics of meningiomas: from basic research to potential clinical applications. Neurosurgery 60: 787-798, 2007.

38 Cong $\mathrm{F}$ and Varmus H: Nuclear-cytoplasmic shuttling of Axin regulates subcellular localization of beta-catenin. Proc Natl Acad Sci USA 101: 2882-2887, 2004

39 Anderson CB, Neufeld KL and White RL: Subcellular distribution of Wnt pathway proteins in normal and neoplastic colon. Proc Natl Acad Sci USA 99: 8683-8688, 2002.

40 Wiechens N, Heinle K, Englmeier L, Schohl A and Fagotto F: Nucleo-cytoplasmic shuttling of Axin, a negative regulator of the Wnt-beta-catenin Pathway. J Biol Chem 279: 5263-5267, 2004.

41 da Silva R, Marie SKN, Uno M, Matushita H, Wakamatsu A, Rosemberg S and Oba-Shinjo SM: CTNNB1, AXIN1 and APC expression analysis of different medulloblastoma variants. Clinics 68: 167-172, 2013.

42 Brunner EC, Romeike BF, Jung M, Comtesse N and Meese E: Altered expression of beta-catenin/E-cadherin in meningiomas Histopathology 49: 178-187, 2006.

43 Wrobel G, Roerig P Kokocinski F Neben K, Hahn M, Reifenberger $\mathrm{G}$ and Lichter P: Microarray-based gene expression profiling of benign, atypical and anaplastic meningiomas identified novel genes associated with meningioma progression. Int J Cancer 114: 249-256, 2005.

44 Dahmen RP, Koch A, Denkhaus D, Tonn JC, Sörensen N, Berthold F, Behrens J, Birchmeier W, Wiestler OD and Pietsch T: Deletions of AXIN1, a component of the WNT/wingless pathway, in sporadic medulloblastomas. Cancer Res 61: 7039-7043, 2001.

45 Beaza N, Masuoka J, Kleihues P and Ohgaki H: AXIN1 mutations but not deletions in cerebellar medulloblastomas. Oncogene 22: 632-636, 2003.

46 Zhang LY, Ye J, Zhang F, Li FF, Li H, Gu Y, Liu F, Chen GS and $\mathrm{Li}$ Q: Axin induces cell death and reduces cell proliferation in astrocytoma by activating the p53 pathway. Int $\mathrm{J}$ Oncol 35 : 25-32, 2009

47 Lu J, Zhang F, Zhao D, Hong L, Min J, Zhang L, Li F, Yan Y, Li H, Ma Y and Li Q: ATRA-inhibited proliferation in glioma cells is associated with subcellular redistribution of beta-catenin via up-regulation of Axin. J Neurooncol 87: 271-277, 2008.

48 Jin LH, Shao QJ, Luo W, Ye ZY, Li Q and Lin SC: Detection of point mutations of the Axin 1 gene in colorectal cancers. Int J Cancer 107: 696-699, 2003.

49 Fearnhead NS, Wilding JL, Winney B, Tonks S, Bartlett S, Bicknell DC, Tomlinson IP, Mortensen NJ and Bodmer WF: Multiple rare variants in different genes account for multifactorial inherited susceptibility to colorectal adenomas. Proc Natl Acad Sci USA 101: 15992-15997, 2004.
50 Segditsas S and Tomlinson I: Colorectal cancer and genetic alterations in the Wnt pathway. Oncogene 25: 7531-7537, 2006.

51 Satoh S, Daigo Y, Furukawa Y, Kato T, Miwa N, Nishiwaki T, Kawasoe T, Ishiguro H, Fujita M, Tokino T, Sasaki Y, Imaoka S, Murata M, Shimano T, Yamaoka Y and Nakamura Y: AXIN1 mutations in hepatocellular carcinomas, and growth suppression in cancer cells by virus-mediated transfer of AXIN1. Nat Genet 24: 245-250, 2000

52 Taniguchi K, Roberts LR, Aderca IN, Dong X, Qian C, Murphy LM, Nagorney DM, Burgart LJ, Roche PC, Smith DI, Ross JA and Liu W: Mutational spectrum of beta-catenin, AXIN1, and AXIN2 in hepatocellular carcinomas and hepatoblastomas. Oncogene 21: 4863-4871, 2002.

53 Mazzoni SM and Fearon ER: AXIN1 and AXIN2 variants in gastrointestinal cancers. Cancer Lett 355: 1-8, 2014.

54 Yardy GW, Bicknell DC, Wilding JL, Bartlett S, Liu Y, Winney B, Turner GD, Brewster SF and Bodmer WF: Mutations in the AXIN1 gene in advanced prostate cancer. Eur Urol 56: 486-494, 2009.

$55 \mathrm{Wu}$ R, Zhai Y, Fearon ER and Cho KR: Diverse mechanism of beta-catenin deregulation in ovarian endometrioid adenocarcinomas. Cancer Res 61: 8247-8255, 2001.

56 Xu HT, Yang LH, Li QC, Liu SL, Liu D, Xie XM and Wang EH: Disabled-2 and Axin are concurrently colocalized and underexpressed in lung cancers. Hum Pathol 42: 1491-1498, 2011.

57 Nakajima M, Fukuchi M, Miyazaki T, Masuda N, Kato H and Kuwano H: Reduced expression of Axin correlates with tumour progression of oesophageal squamous cell carcinoma. Br J Cancer 88: 1734-1739, 2003.

58 Guimier A, Ragazzon B, Assié G, Tissier F, Dousset B, Bertherat $\mathrm{J}$ and Gaujoux S: AXIN genetic analysis in adrenocortical carcinomas updated. J Endocrinol Invest 36: 1000-1003, 2013.

59 Zhou CX and Gao Y: Frequent genetic alterations and reduced expression of the Axin 1 gene in oral squamous cell carcinoma: involvement in tumor progression and metastasis. Oncol Rep 17: 73-79, 2007.

60 Sun C, Yamato T, Kondo E, Furukawa T, Ikeda H and Horii A: Infrequent mutation of APC, AXIN1 and GSK3B in human pituitary adenomas with abnormal accumulation of CTNNB1. J Neurooncol 73: 131-134, 2005.

61 Lee Y, Liu J, Patel S, Cloughesy T, Lai A, Farooqi H, Seligson D, Dong J, Liau L, Becker D, Mischel P, Shams S, Nelson S: Genomic landscape of meningiomas. Brain Pathol 20: 751-762, 2010.

62 Miller R Jr., DeCandio ML, Dixon-Mah Y, Giglio P, Vandergrift WA3rd, Banik NL, Patel SJ, Varma AK, Das A: Molecular Targets and Treatment of Meningioma. J Neurol Neurosurg 1: pii: 1000101, 2014.

63 Pérez-Magán E, Rodríguez de Lope A, Ribalta T, Ruano Y, Campos-Martín Y, Pérez-Bautista G, García JF, García-Claver A, Fiaño C, Hernández-Moneo J-L, Mollejo M, Meléndez B: Differential expression profiling analyses identifies downregulation of $1 \mathrm{p}, 6 \mathrm{q}$, and $14 \mathrm{q}$ genes and overexpression of $6 \mathrm{p}$ histone cluster 1 genes as markers of recurrence in meningiomas. Neuro Oncol 12: 1278-1290, 2010.

64 Watson MA, Gutmann DH, Peterson K, Chicoine MR, Kleinschmidt-DeMasters BK, Brown HG, Perry A: Molecular characterization of human meningiomas by gene expression profiling using high-density oligonucleotide microarrays. Am J Pathol 161: 665-672, 2002. 
65 Domingues PH, Teodósio C, Otero Á, Sousa P, Gonçalves JM, Nieto AB, Lopes MC, de Oliveira C, Orfao A, Tabernero MD: The protein expression profile of meningioma cells is associated with distinct cytogenetic tumour subgroups. Neuropathol Appl Neurobiol 41: 319-332, 2015.

66 Levina E, Oren M, Ben-Ze'ev A: Down-regulation of betacatenin by 553 involves changes in the rate of beta-catenin phosphorylation and Axin dynamics. Oncogene 23: 4444-4453, 2004.

67 Pećina-Šlaus N, Kafka A, Vladušić T, Tomas D, Logara M, Skoko J, Hrašćan R: Loss of p53 expression is accompanied with up-regulation of beta-catenin in meningiomas: a concomitant reciprocal expression. Int J Exp Pathol 97: 159-169, 2016.

68 Sadot E, Geiger B, Oren M, Ben-Ze'ev A: Down-regulation of beta-catenin by activated p53. Mol. Cell Biol 21: 6768-6781, 2001.

69 Schwechheimer K, Zhou L, Birchmeier W: E-Cadherin in human brain tumours: loss of immunoreactivity in malignant meningiomas. Virchows Arch 432: 163-167, 1998.

70 Utsuki S, Oka H, Sato Y, Kawano N, Tsuchiya B, Kobayashi I, Fujii K: Invasive meningioma is associated with a low expression of E-cadherin and beta-catenin. Clin Neuropathol 24: 8-12, 2005.
71 Saydam O, Shen Y, Würdinger T, Senol O, Boke E, James MF, Tannous BA, Stemmer-Rachamimov AO, Yi M, Stephens RM, Fraefel C, Gusella JF, Krichevsky AM, Breakefield XO: Downregulated microRNA-200a in meningiomas promotes tumor growth by reducing E-cadherin and activating the Wnt/betacatenin signaling pathway. Mol Cell Biol 29: 5923-5940, 2009.

72 Skiriute D, Tamasauskas S, Asmoniene V, Saferis V, Skauminas $\mathrm{K}$, Deltuva V, Tamasauskas A: Tumor grade-related NDRG2 gene expression in primary and recurrent intracranial meningiomas. J Neurooncol 102: 89-94, 2011.

73 Kim JT, Kim JW, Kang YH, Kim KD, Lee SJ, Choi SC, Kim KS,Chae SK, Kim JW, Lim JS, Lee HG: NDRG2 and PRA1 interact and synergistically inhibit T-cell factor/ $\beta$-catenin signaling. FEBS Lett 586: 3962-3968, 2012.

74 Kim MJ, Lim J, Yang Y, Lee MS, Lim JS: N-myc downstreamregulated gene 2 (NDRG2) suppresses the epithelialmesenchymal transition (EMT) in breast cancer cells via STAT3/Snail signaling. Cancer Lett 354: 33-42, 2014.

Received July 16, 2016

Revised July 8, 2016

Accepted July 21, 2016 